\title{
DESIGN OF PR FRAMES WITH TOP AND SEAT ANGLE CONNECTIONS USING THE DIRECT ANALYSIS METHOD
}

\author{
Rampal Singh ${ }^{1}$ and Eric M. Lui ${ }^{2, *}$ \\ ${ }^{1}$ Graduate Assistant \\ ${ }^{2}$ Meredith Professor \\ Department of Civil and Environmental Engineering, Syracuse University, Syracuse, NY 13244-1240, USA \\ *(Corresponding author: E-mail: emlui@syr.edu)
}

Received: 9 August 2012; Revised: 2 February 2013; Accepted: 18 February 2013

\begin{abstract}
Partially restrained (PR) connections are connections that possess stiffness and moment characteristics that fall between the extreme cases of pinned and rigid. This paper proposes a design methodology for PR frames that takes into consideration the semi-rigid nature of the connections, including their loading/unloading behavior under combined gravity and wind loads. Top and seat angle connections, modeled using the three-parameter power model, are used to demonstrate the proposed design procedure. To simply the design, two linearized connection stiffness values calculated on the basis of expected connection loads are used. The analysis is carried out using the American Institute of Steel Construction (AISC) direct analysis method in which notional horizontal loads, expressed as a fraction of the gravity load, are applied to the PR frames in conjunction with the use of reduced member axial and bending stiffness. Examples are given to demonstrate the validity of the proposed method of PR frame design. Keywords: Partially restrained frames, Top and seat angle connections, Direct analysis method, Steel structures, Design and analysis
\end{abstract}

\section{INTRODUCTION}

Connections are important structural elements in a frame structure. The behavior of the frame is very much affected by the types of connections used. If the connection possesses sufficient strength and stiffness, full continuity between the connected elements can be assumed for analysis and design. However, if either the connection strength or stiffness falls short of what is assumed, allowances must be made in the analysis and design processes to ensure that the frame will behave as expected. In a conventional analysis and design of steel frames, a simplifying assumption that the beam-to-column connections are either fully rigid or ideally pinned is often used. The rigid joint assumption implies that full slope continuity exists between the adjoining members, which means the angle between the beam and column remains more or less unchanged as the frame deforms; and the full or a substantial amount of moments is transferred between the beam and the column. On the other extreme, the assumption of an ideally pinned connection implies that no or very little moment will be transmitted between the beam and the column and as far as rotation is concerned the beam and column will behave independently.

Although the use of these idealized joint bebavior drastically simplifies the analysis and design procedures, the validity of these assumptions becomes questionable for cases in which the rigidity of connections, which can be considered as the slope of the relation between the connection moment $M$ and the connection relative rotation $\theta$, is intermediate between the fully rigid and ideally pinned cases. These connections, referred to as semi-rigid or partially restrained (PR) connections, have been the subject of research for many years, and various researchers have proposed analysis and design methods for frames that utilize these PR connections (Ang and Morris [1], Lui and Chen [2,3,4], Chen [5], Cunningham [6], Wu and Chen [7], Barakat and Chen [8,9], Hsieh and Deierlein[10], Lui [11], Xu [12], Surovek et al. [13]). Detailed summaries of research on PR connections and frames can be found in a number of books and monographs such as those by Narayanan [14], Lorenz et al. [15], Chen et al. [16], Bjorhovde et al. [17], Chan and Chui [18], Chen [19], Faella et al. [20], Chen et al. [21], etc., and will not be repeated here. 
According to the American Institute of Steel Construction (AISC [22]) specification, a connection is considered to be a PR connection if its secant stiffness under service load $R_{k s}$ falls in the range $2 E I / L<R_{k s}<20 E I / L$, where $E I$ and $L$ are the flexural rigidity and the length of the adjoining beam, respectively. Despite acknowledging the existence of PR connections in frame structures and suggesting that the relevant response characteristics of PR connections must be included in the analysis of the structure for member and connection forces, displacements and frame stability, no recommendations are currently given in the AISC specification on how these PR frames should be designed. In addition, for the first time AISC is espousing the direct analysis method as the main design method for stability, while the commonly-used effective length method, first-order analysis method, and approximate second-order analysis using moment magnification $\left(B_{1}, B_{2}\right)$ factors have been relegated to the appendix. It is therefore the objective of this paper to propose a design method for PR frames using the direct analysis approach.

\section{CONNECTION TYPES, CLASSIFICATIONS AND BEHAVIOR}

There are various means by which connections can be classified. For instance, they can be classified by the connecting medium used, e.g., bolted versus welded connections. They can also be classified by their functionality, e.g., beam-to-column connections, hanger connections, bracing connections, truss connections, etc.; or by the type of internal forces/moment that will be transmitted, e.g., shear versus moment connections; or by the types and geometries of connection elements used, e.g., single plate connections, double web angle connections, top and seat angle connections, flange-angle connections, end plate connections, flange-plated connections, etc. Regardless of how connections are classified, the behavior of connections is often described by their moment-rotation $(M-\theta)$ response as shown in Figure 1. Although connections do experience axial, shear and torsional deformations, they are usually small compared to the rotational deformation. Consequently, researchers often consider only the connection's rotational deformation in assessing frame response. Aside from a few exceptions (Cerfontaine and Jaspart [23], Urbonas and Daniunas [24,25]), almost all experiments on connections conducted in the past few decades have focused primarily on their flexural response, and over the years several connection database and various connection models have been developed for general use (Frye and Morris [26], Goverdhan [27], Ang and Morris [1], Nethercot [28], Kishi and Chen [29], Chen and Kishi [30], Chen et al. [21]). From these database, it can be observed that (1) almost all types of connections exhibit a $M-\theta$ behavior that falls between the extreme cases of ideally pinned and fully rigid conditions, (2) except for small values of moment the $M-\theta$ relationships are typically nonlinear over a large range of loading, and (3) the maximum moment a connection can transmit often decreases with the more flexible connection (i.e., there is a correlation between strength and stiffness).

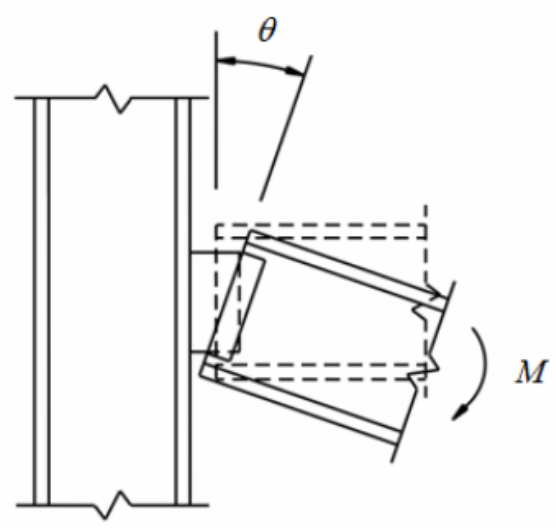

Figure 1. Flexural (or Rotational) Deformation of a PR Connection under a Moment 
Because of the above observations, connections can also be classified according to their stiffness or strength (see for example Bjorhovde et al. [31], Eurocode 3 [32], Nethercot et al. [33], AISC [22]). Since the AISC direct analysis procedure will be used, the AISC connection classification scheme will be adopted for the present study. For a connection to be classified as a PR connection, its secant stiffness $R_{k s}$ under service load (i.e., the slope of a straight line drawn from the origin to the moment Ms under service load condition as shown in Figure 2) falls in the range $2 E I / L$ $<R_{k s}<20 E I / L$, where $E I$ and $L$ are the flexural rigidity and the length of the beam, respectively. In terms of strength, a PR connection should be able to transmit at least $20 \%$ of the full plastic moment of the beam when it is experiencing a rotation $\theta=0.02$ radian. Furthermore, it should possess sufficient rotational capacity so that $\theta_{u}$, defined as the connection rotation where its strength has dropped to $80 \%$ of its peak value as shown in Figure 2 or a rotational deformation equal to 0.03 radian if the connection experiences little or no loss in strength, will exceed what is required for design at the strength limit state.

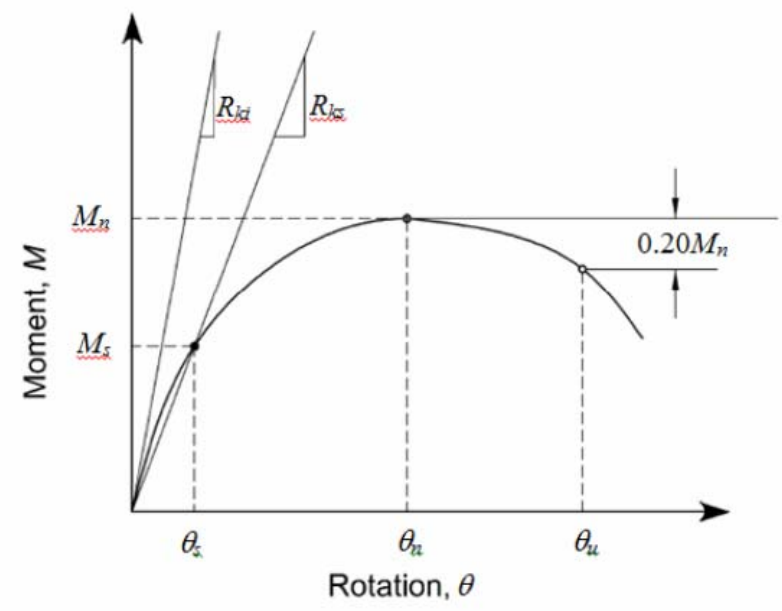

Figure 2. Moment-rotation Response of a PR Connection

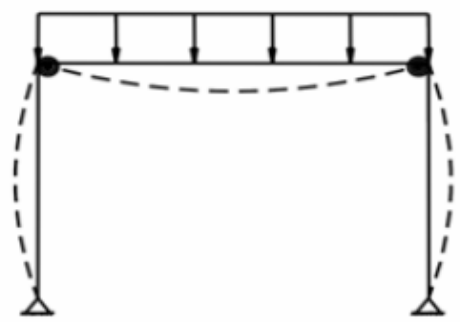

(a)

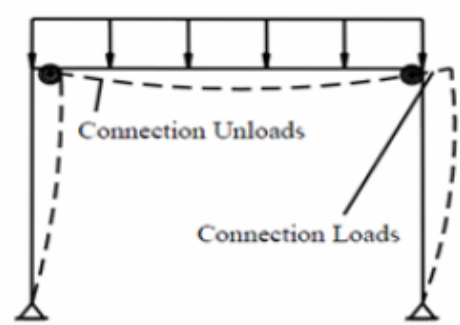

(b)

Figure 3. Loading/Unloading Behavior of PR Connections -

(a) Both Connections Load under Gravity Load,

(b) Windward Connection Unloads while Leeward Connection Loads under Wind Load 
Another aspect of PR connections that needs to be addressed is their loading/unloading response to load sequencing. With reference to Figure 3 in which a simple portal frame is shown with PR connections present at both beam-column joints. When the gravity load is applied, both connections undergo loading. However, when a lateral load such as wind is applied, the windward connection will experience unloading while the leeward connection will continue to undergo loading. Depending on the difference between the loading and unloading stiffness, the forces and moments developed in the frame can be quite different. The design procedure for PR frame to be discussed in a later section will account for this connection loading/unloading response.

\section{CONNECTION MODEL}

Almost all $M-\theta$ data for PR connections are obtained from laboratory tests. These test data are then curve-fitted to provide empirical equations for use in analysis and design. Many such equations in the form of linear, bilinear, trilinear, polynomial, spline, exponential, and power functions have been proposed (Frye and Morris [26], Goverdhan [27], Ang and Morris [1], Nethercot [28], Kishi and Chen [29], Chen and Lui [34]), and computer programs (PRCONN [35], Chen and Toma [36], Chen et al. [21]) are available from which information on a number of PR connection types can be retrieved. In the present study, the three-parameter power model (Kishi et al. [37,38], Kishi and Chen [39]) for connections made from angle sections will be used. In this model the initial connection stiffness $R_{k i}$ and ultimate moment capacity $M_{u l t}$ of the connections were determined using mechanistic models. Using these two quantities plus a curve-fitting shape factor $n$, the experimental data were represented by an equation in the form (Richard and Abbott [40])

$$
M=\frac{R_{k i} \theta}{\left[1+\left(\frac{\theta}{\theta_{o}}\right)^{n}\right]^{1 / n}}
$$

where

$R_{k i} \quad=$ initial connection stiffness

$n \quad=$ shape factor

$\theta_{o} \quad=$ reference plastic rotation, calculated as $\theta_{o}=M_{u l t} / R_{k i}$

$M_{u l t} \quad=$ ultimate moment capacity of the connection

As shown in Figure 4, the shape factor $n$ defines the shape of the $M-\theta$ curve for a given set of $R_{k i}$ and $M_{u l t}$ values.

Equations for $R_{k i}, M_{u l t}$ and $n$ for connections made from angle sections have been derived (Kishi et al. [41]). With reference to a typical connection angle shown in Figure 5, if we define

$g_{c}=$ distance between heel of angle to center of first line of fasteners

$k=$ gauge distance from heel of angle to top of fillet

$t=$ angle thickness

$W=$ nut width

and denote

$d$ =beam depth

$l=$ angle length

$I_{o}=t^{3} / 12=$ geometrical moment of inertia

$M_{o}=\sigma_{y} t^{2} / 4=$ moment per unit length of angle

$\sigma_{y}=$ yield stress of angle 


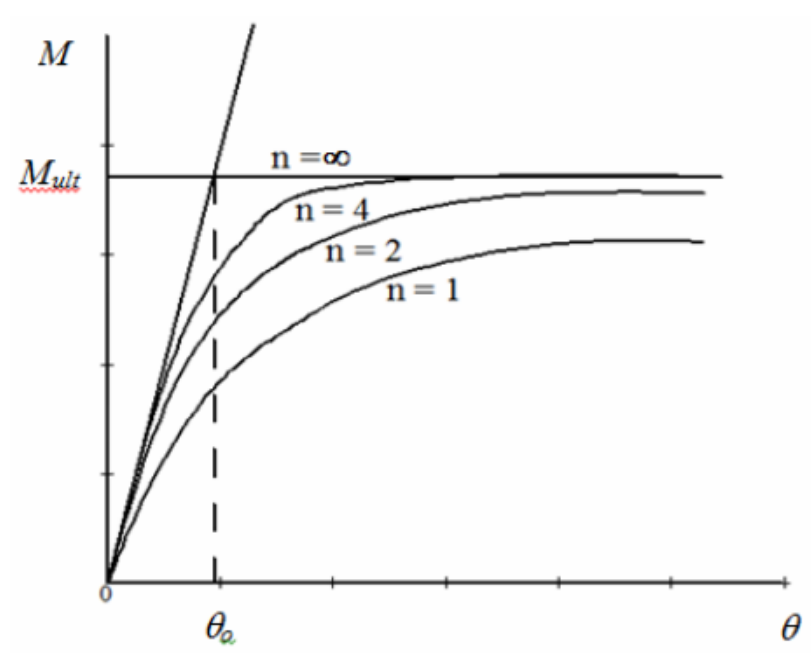

Figure 4. Three-parameter Power Connection Model

as well as with the use of the following non-dimensional parameters

$\beta=g_{c} l l, \quad \gamma=l / t, \quad \delta=d / t, \quad \kappa=k / t, \quad \omega=W / t, \quad \rho=t_{w} / t_{t}$

where subscripts $t$ and $w$ denote the top angle and the web angle, respectively, the equations for the three parameters $R_{k i}, M_{u l t}$ and $n$ are given as follows.

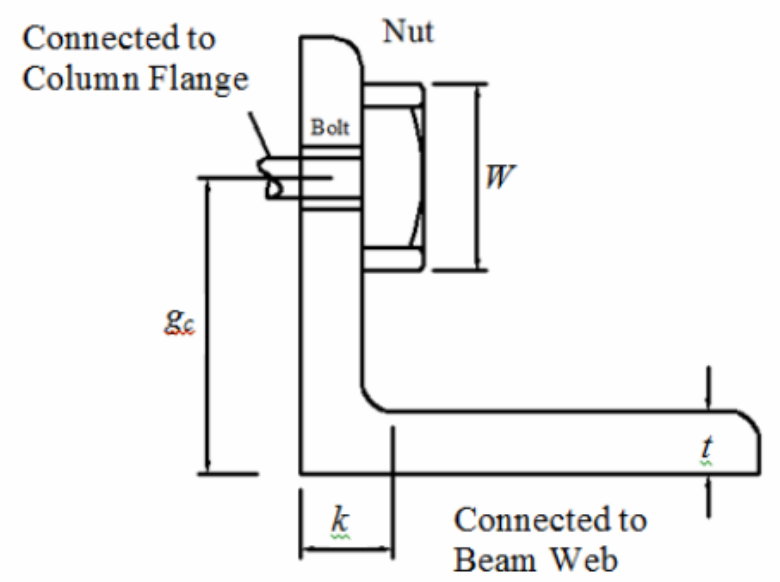

Figure 5. Symbols used for an Angle Connection

\subsection{Initial Connection Stiffness $\boldsymbol{R}_{k i}$}

The equation for the initial connection stiffness is

$\frac{R_{k i}}{E I_{o t}}=\frac{R_{k i t s}}{E I_{o t}}+\frac{R_{k i w}}{E I_{o t}}$

where $R_{k i t s} / E I_{o t}$ and $R_{k i w} / E I_{o t}$ are the non-dimensional top and seat angle and web angle stiffness contributions to the initial connection stiffness, respectively. They are given by

$\frac{R_{\text {kits }}}{E I_{o t}}=\frac{3\left(1+\delta_{t}\right)^{2}}{\beta_{t}^{\prime}\left[\gamma_{t}^{2}\left(\beta_{t}^{\prime}\right)^{2}+0.78\right]}$ 


$$
\frac{R_{k i w}}{E I_{o t}}=\frac{3 \rho\left(1+\delta_{t}\right)^{2}}{2 \beta_{w}^{\prime}\left[\gamma_{w}^{2}\left(\beta_{w}^{\prime}\right)^{2}+0.78\right]}
$$

in which

$E I_{o t}=29000 \cdot \frac{t_{t}^{3}}{12}$

$\mathcal{\beta}_{t}^{\prime}=\beta_{t}-\frac{1}{2 \gamma_{t}} 1+? \omega_{t}$

$\mathcal{\beta}_{w}^{\prime}=\beta_{w}-\frac{1}{2 \gamma_{w}} 1+? \omega_{w}$

\subsection{Ultimate Connection Moment Capacity $M_{u l t}$}

The equation for the ultimate connection moment capacity is

$\frac{M_{u l t}}{M_{o t} t_{t}}=\frac{M_{u t s}}{M_{o t} t_{t}}+\frac{M_{u w}}{M_{o t} t_{t}}$

where $M_{u t s} / M_{o t} t_{t}$ and $M_{u w} / M_{o t} t_{t}$ are the top and seat angle and web angle moment contributions to the ultimate connection moment capacity, respectively. They are given by

$$
\begin{aligned}
& \frac{M_{u t s}}{M_{o t} t_{t}}=\gamma_{t}\left\{1+\xi_{t}\left[1+\beta_{t}^{*}+2\left(\kappa_{t}+\delta_{t}\right)\right]\right\} \\
& \frac{M_{u w}}{M_{o t} t_{t}}=\gamma_{w}\left(1+\xi_{w}\right) \rho^{3}\left[\frac{\gamma_{w}\left(\xi_{w}-1\right)}{3\left(\xi_{w}+1\right)}+\delta_{w}+\frac{1}{\rho}\right]
\end{aligned}
$$

where

$$
M_{o t}=\frac{\sigma_{y} t_{t}^{2}}{4}
$$

and $\xi_{t}$ and $\xi_{w}$ are to be evaluated from the following fourth-order equations

$\xi_{t}^{4}+\beta_{t}^{*} \xi_{t}-1=0$

$\xi_{w}^{4}+\beta_{w}^{*} \xi_{w}-1=0$

where

$$
\begin{aligned}
& \beta_{t}^{*}=\beta_{t}^{\prime} \gamma_{t}-\kappa_{t} \\
& \beta_{w}^{*}=\beta_{w} \gamma_{w}-\kappa_{w}
\end{aligned}
$$

with $\beta_{t}^{\prime}$ computed from Eq. 7. 
It should be noted that even though Eqs. 3 and 9 were derived for top and seat angle connections with double web angles, they can be simplified for top and seat angles without the web angles by setting the second term equal zero, or for double web angle connections by setting the first term equal zero, or for single web angle connections by setting the first term equal zero and dividing the second term by 2 .

\subsection{Shape Parameter $n$}

The equations for the shape parameter are given as follows.

For top and seat angle connections with the web angles:

$n=1.398 \log _{10} \theta_{o}+4.631 \geq 0.827$

For top and seat angle connections without the web angles:

$n=2.003 \log _{10} \theta_{o}+6.070 \geq 0.302$

For double web angle connections:

$n=1.322 \log _{10} \theta_{o}+3.952 \geq 0.573$

For single web angle connections:

$n=0.520 \log _{10} \theta_{o}+2.291 \geq 0.695$

Because of some uncertainties in test setups and data collections, the loss of accuracy during the curve-fitting process, and the unavoidable variability of one connection to another, a resistance factor of 0.9 as recommended by Christopher and Bjorhovde [42] will be used in the proposed method of PR frame design.

\section{AISC DIRECT ANALYSIS METHOD}

The direct analysis method is a method recommended by AISC for use in the stability analysis and design of frame structures. It has the following features:

1. A second-order elastic analysis that explicitly accounts for the $P-\delta$ and $P-\Delta$ effects is to be used to determine the required strengths. However, it is permissible to neglect the $P-\delta$ effect in the analysis (but not in design) if (a) the gravity loads are supported primarily by nominally vertical columns, walls or frames, (b) the ratio of maximum second-order drift to first-order drift both calculated using adjusted stiffness (see Items 3 and 4 below) for all stories is $\leq 1.7$, and (c) no more than one-third of the total gravity loads on the structure is supported by columns that are part of the moment-resisting frame in the direction of translation being considered. In lieu of a second-order analysis, the use of a first-order analysis in conjunction with the use of moment magnification (i.e., $B_{1}$ and $B_{2}$ ) factors is permitted.

2. The effect of initial imperfections in the form of column out-of-plumbness is to be considered in the analysis by including them directly in the structural model. The magnitude of the initial displacements shall be the maximum amount considered in the design, and the pattern of initial displacements shall be such that it provides the greatest destabilizing effect. Alternatively, for structures that support gravity loads primarily through nominally vertical columns, walls or frames, the effect of initial imperfections can be represented using notional loads. In this approach, notional lateral loads of magnitude $0.002 \sum P_{i}$ (where $\sum P_{i}$ is the factored gravity loads acting on story $i$ ) distributed over the story 
in the same proportion as the gravity loads are to be applied to the story for all gravity-only load combinations. However, for frames where the ratio of second-order to first-order drift (both computed using the adjusted stiffness discussed in Items 3 and 4 below) exceeds 1.7, these notional lateral loads have to be applied to all load combinations in the analysis.

3. A reduced stiffness equal to $0.8 E$ is to be used for members whose flexural or axial stiffness is considered to contribute to the lateral stability of the frame. Conservatively, the use of $0.8 E$ for all members is permitted. This stiffness reduction is used to account for the effects of member imperfections and inelasticity, as well as uncertainty in determining the member strength and stiffness.

4. If $P_{u} / P_{y}>0.5$ (where $P_{u}$ is the required axial compressive strength and $P_{y}=F_{y} A$ is the yield load), a second stiffness reduction factor, $\tau=4\left(P_{u} / P_{y}\right)\left[1-\left(P_{u} / P_{y}\right)\right]$ is to be applied to the moment of inertia $I$ of all flexural members that contribute to the lateral stiffness of the frame. In lieu of using $\tau$, an increase of the notional from $0.002 \sum P_{i}$ to $0.003 \sum P_{i}$ can be used in all load combinations.

5. Regardless of the end conditions of the member, an effective length factor of $K=1$ is to be used to compute the design compressive strength $P_{n}$ of the member.

\section{PROPOSED PR FRAME DESIGN APPROACH}

The steps proposed for the design or PR frames are as follows:

1. For each semi-rigid connection, assume a value of $\bar{R}_{k}=R_{k b} L / E I$, where $R_{k b}$ is the effective linearized connection stiffness under factored gravity loads. It is obtained as the slope of a line drawn from the origin to the intersection point of the PR connection $M-\theta$ curve and a beam line (see Figure 6). The beam line is defined by the equation

$M=\frac{w_{u} L^{2}}{12}-\frac{2 E I}{L} \theta$

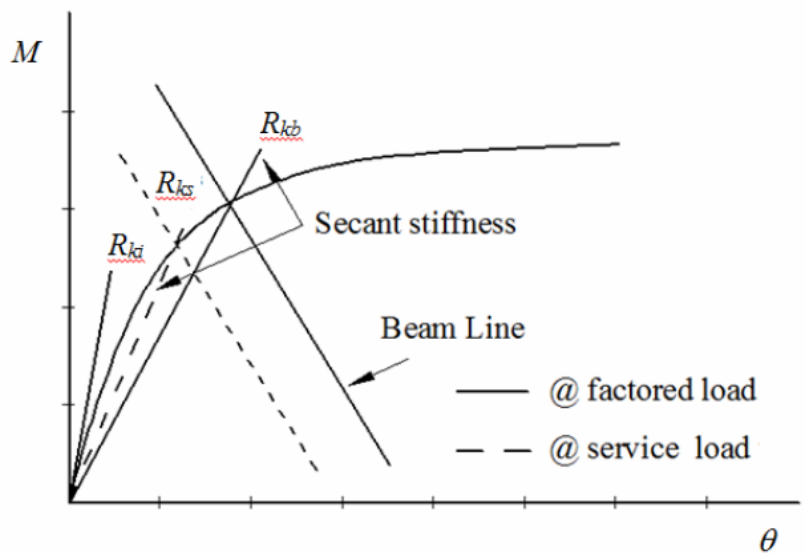

Figure 6. Determination of $R_{k b}$

where $w_{u}$ is the uniform factored gravity load on the beam. The above equation relates the end moment $M$ and rotation $\theta$ of a prismatic beam subject to a uniformly distributed load applied over its entire length. Note that if the connection is fully-rigid, $\theta=0$ and so $M=$ $w_{u} L^{2} / 12$, which is the fixed-end moment of the beam. On the other hand, if the connection is ideally-pinned, $M=0$ and so $\theta=w_{u} L^{3} / 24 E I$, which is the end rotation of a simply-supported beam. 
2. Calculate the beam moments $M_{n e g}$ and $M_{\text {pos }}$ for the assumed value of $\bar{R}_{k}$ using the following equations (Chen and Lui [34]).

$$
\begin{aligned}
& M_{n e g}=\frac{2 \bar{R}_{k b}}{3\left(\bar{R}_{k b}+2\right)} M_{s s} \\
& M_{p o s}=\frac{\bar{R}_{k b}+6}{3\left(\bar{R}_{k b}+2\right)} M_{s s}
\end{aligned}
$$

where $M_{s S}=w_{u} L^{2} / 8$ is the uniformly loaded simply-supported beam moment.

3. Select trial beam section based on the calculated $M_{p o s}$ and $M_{n e g}$ values.

4. Select the type of connection (e.g., a top and seat angle connection with double web angles) and choose a family of connections (3 to 4 etc.) as trials.

5. Determine the $M-\theta$ curve parameters $\left(M_{u l t}, R_{k i}\right.$, and $\left.n\right)$ for each connection using the procedure outlined in Section 3.

6. Construct a family of $M-\theta$ curves using Eq. 1, and superimpose on them a beam-line computed using Eq. (18)

7. Select an appropriate connection by determining the $R_{k b}$ values for the family of connections and choose the one that has a $\bar{R}_{k}\left(=R_{k b} L / E I\right)$ value closest to the one assumed in Step 1.

8. Determine $R_{k s}$ as shown in Figure 6 and calculate $R_{k s} L / E I$ for the selected connection at service load to check that it falls in the PR connection range of $2<R_{k s} L / E I<20$.

9. Select the trial column section based on the factored axial load and moment.

10. For unbraced frames, calculate the loading stiffness $R_{k L}$ using the equation

$$
R_{k L}=\frac{M_{n}-M_{g}}{\theta_{n}-\theta_{g}}
$$

where, in reference to Figure 7, $M_{n}$ is the nominal moment strength of the connection that corresponds to $\theta_{n}=0.02$ radian (AISC [22]) denoted as point $\mathrm{b}$ in the figure, and $M_{g}$ and $\theta_{g}$ are the moment and rotation of the connection under factored gravity loads denoted as point a.

11. Analyze the PR frame using the appropriate connection stiffness $R_{k b}, R_{k L}$ or $R_{k i}$ in conjunction with the Direct Analysis Method for the two cases described below.

Case 1, the non-sway frame condition for gravity load combinations only:

\begin{tabular}{rlrl}
\hline Element Stiffness & - Column: & & $E I_{e}=0.8 \tau E I$ \\
& - Beams: & $E I_{e}=0.8 E I$ \\
- Connections: & $R_{k}=0.9 R_{k b}$
\end{tabular}

Applied Loads - gravity load combinations, plus a notional load of $0.002 P_{i}$ applied to each column at each floor level.

-Perform a second-order elastic analysis to determine the internal forces.

- Check the beam-column, beam, and connection strength.

-If the above conditions are satisfied, proceed further. Otherwise, revise the sections and/or connections until the conditions are satisfied. 


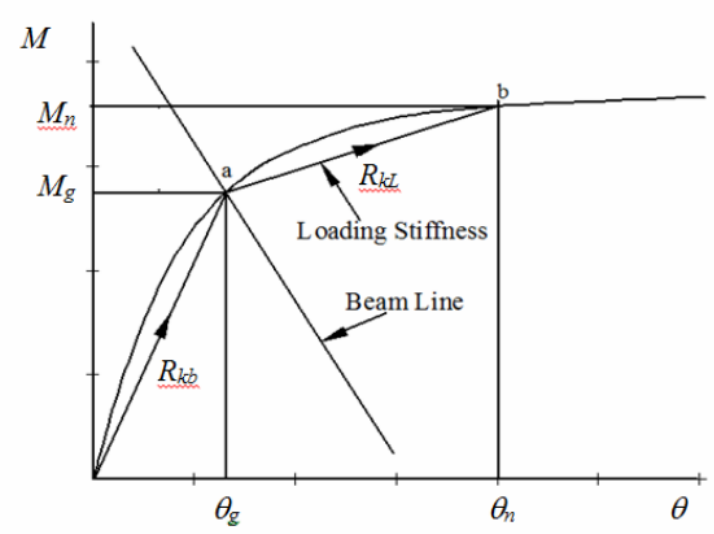

Figure 7. Determination of $R_{k L}$

Case 2, the sway frame condition for gravity + lateral load combinations:

Step 1 - Gravity load step:

$$
\begin{array}{lll}
\text { Element Stiffness } & \text { - Column: } & E I_{e}=0.8 \tau E I \\
& \text { - Beams: } & E I_{e}=0.8 E I \\
& \text { - Connections: } & R_{k}=0.9 R_{k b} \\
\text { Applied Loads } & \text { - Factored gravity loads only without any notional loads }
\end{array}
$$

-Perform a second-order elastic analysis to determine the internal forces due to the applied loads.

Step 2 - Lateral load step:

$$
\begin{array}{lll}
\text { Element Stiffness } & - \text { Column: } & E I_{e}=0.8 \tau \mathrm{E} I \\
\text { - Beams: } & E I_{e}=0.8 E I \\
\text { - Connections: } & R_{k}=0.9 R_{k i} \text { (Windward Side) } \\
& R_{k}=0.9 R_{k L} \text { (Leeward Side) }
\end{array}
$$

Applied Loads - Concentrated vertical loads applied at beam-column joints producing the column axial forces associated with Step 1

- Lateral load combinations plus a notional load of $0.002 P_{i}$ applied to each column at each floor level

-Perform a second-order elastic analysis to determine the internal forces due to above applied loads

-Superimpose the moments from the gravity (step 1) and lateral (step 2) load steps. Check the beam-column, beam and connection strengths. If not satisfied, revise the sections and/or connections of the structure.

\section{DESIGN EXAMPLES}

In this section, design examples will be given to show how the proposed PR frame design procedure presented in the preceding section can be applied. The second-order analysis is performed using the software MASTAN2 (McGuire et al. [43]). 
The first example (a portal frame) is used to demonstrate the basic loading/unloading behavior of PR connections in an unbraced frame when one end of a beam/girder is connected to a single column. It also serves to show the effect of PR connections on the columns. The second example (a 2-story unbraced frame) is used to demonstrate how the moments can be distributed to the columns above and below the beam to which the columns are attached. In both examples, only top and seat angle with double web angle connections will be considered. This is because the normalized stiffness $\bar{R}_{k}$ for this type of connections often falls in the semi-rigid range of $2<\bar{R}_{k}<$ 20 , and so they are commonly used in PR frames. In addition, the following assumptions have been used:

- All beam sections are compact (i.e., the sections are capable of developing the full plastic moment)

- All column sections are non-slender elements (i.e., local buckling is not of concern)

- All sections are oriented with their webs in the plane of the applied loads

- The frames are braced against out-of-plane deflection at the beam-column joints only

- The beams are non-composite (i.e., they are not connected to a concrete slab)

- Wind loads are applied as concentrated loads at windward beam-column joints.

- All beam-column connections satisfy the AISC connection design requirements

- All beam and column sections are W-shapes made from A992 steel with $F_{y}=50 \mathrm{ksi}$ (345 $\mathrm{MPa})$ and $E=29000 \mathrm{ksi}(200 \mathrm{GPa})$.

\section{Example 1 - Design of a PR Portal Frame}

The PR frame shown in Figure 8 is to be designed. The frame is subjected to the loads shown. Beam deflection under service live load is limited to $L / 360$, where $L$ is the beam length; and frame drift should not exceed $H / 200$, where $H$ is the story height. To start the design, assume $\bar{R}_{k}=6$ for the connections.

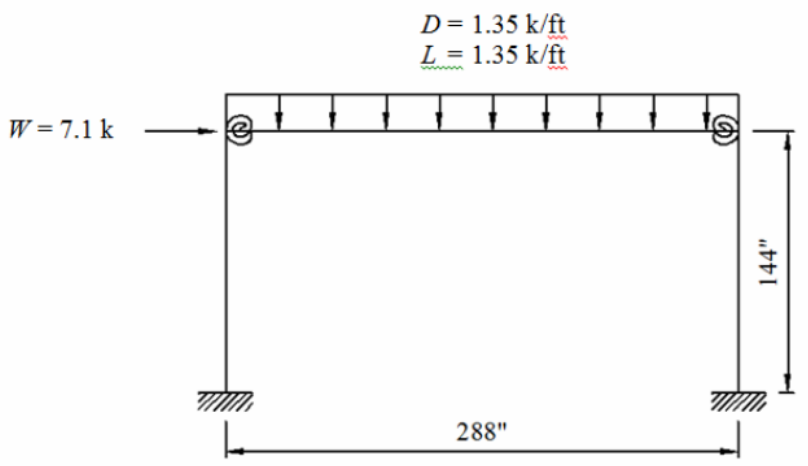

Figure 8. An Unbraced Portal PR Frame $(1 \mathrm{k}=4.45 \mathrm{kN}, 1 \mathrm{ft}=12 ”=0.305 \mathrm{~m})$

\section{Solution:}

Load Combinations: The load combinations (AISC [22], ASCE [44]) that most likely will control the design are given in Table 1.

Table 1. Applied loads $(1 \mathrm{k} / \mathrm{in} .=175 \mathrm{kN} / \mathrm{m}, 1 \mathrm{kip}=4.45 \mathrm{kN})$

\begin{tabular}{|c|c|c|c|}
\hline Load Case & Load Combinations & $\begin{array}{c}\boldsymbol{w}_{\boldsymbol{u}} \text { (k/in.) } \\
\text { (Gravity) }\end{array}$ & $\begin{array}{c}\boldsymbol{p}_{\boldsymbol{u}} \text { (kips) } \\
\text { (Lateral) }\end{array}$ \\
\hline 1 & $1.2 D+1.6 L$ & 0.315 & - \\
\hline 2 & $1.2 D+0.5 L+1.0 \mathrm{~W}$ & 0.191 & 7.1 \\
\hline
\end{tabular}


Beam Section Selection: For load case 1, the frame does not undergo any sidesway movement. Use Eqs. (19) and (20) with the assumed $\bar{R}_{k}=6$ to estimate $M_{n e g}$ and $M_{p o s}$ for the preliminary sizing of the beam.

$$
\begin{gathered}
M_{n e g}=\frac{2 \bar{R}_{k b}}{3\left(\bar{R}_{k b}+2\right)} M_{s s}=1633 \mathrm{k}-\mathrm{in} . \\
M_{p o s}=\frac{\bar{R}_{k b}+6}{3\left(\bar{R}_{k b}+2\right)} M_{s s}=1633 \mathrm{k}-\mathrm{in} .
\end{gathered}
$$

Using these moments as a guide, a W14×53 is selected as the trial section. The flexural capacity $\phi_{b} M_{n}$ of this section is $2462 \mathrm{k}$-in. $(278 \mathrm{kN}-\mathrm{m})$, which exceeds the required flexural strength $M_{u}$ (= $M_{\text {neg }}$ or $\left.M_{\text {pos }}\right)=1633 \mathrm{k}$-in. $(185 \mathrm{kN}-\mathrm{m})$.

Connection Selection: If top and seat angle with double web angle connections are to be used for the PR frame, a possible set of candidate connections are summarized in Table 2. In the table, the thickness of the top and seat angle is denoted as C (5/8), C (3/4), etc.

\begin{tabular}{|c|c|c|c|c|c|c|c|c|c|}
\hline \multirow[t]{2}{*}{ Connection } & \multirow{2}{*}{$\begin{array}{c}\text { Bolt } \\
\text { diameter } \\
d \text { (in.) }\end{array}$} & \multirow{2}{*}{$\begin{array}{c}\text { Nut } \\
\text { Width } \\
W \text { (in.) } \\
\end{array}$} & \multicolumn{4}{|c|}{$\begin{array}{c}\text { Top and Seat Angles } \\
2 \mathrm{~L} 6 \times 4 \times t_{t}\end{array}$} & \multicolumn{3}{|c|}{$\begin{array}{c}\text { Web Angles } \\
2 \mathrm{~L} 4 \times 3.5 \times 1 / 2 \\
\end{array}$} \\
\hline & & & $t_{t}$ (in.) & $l_{t}$ (in.) & $g_{c t}$ (in.) & $k_{t}$ (in.) & $l_{w}$ (in.) & $g_{c w}$ (in.) & $k_{w}$ (in.) \\
\hline $\mathrm{C}(5 / 8)$ & $7 / 8$ & $1-7 / 16$ & $5 / 8$ & 7 & 3 & $1-1 / 8$ & 8 & 3 & $11 / 16$ \\
\hline $\mathrm{C}(3 / 4)$ & $7 / 8$ & $1-7 / 16$ & $3 / 4$ & 7 & 3 & $1-1 / 4$ & 8 & 3 & $11 / 16$ \\
\hline $\mathrm{C}(7 / 8)$ & $7 / 8$ & $1-7 / 16$ & $7 / 8$ & 7 & 3 & $1-3 / 8$ & 8 & 3 & $11 / 16$ \\
\hline
\end{tabular}

Table 2. Details of PR Connections ( 1 in. $=25.4 \mathrm{~mm})$

Calculations for $\boldsymbol{R}_{\boldsymbol{k} i}, \boldsymbol{M}_{u l t}$, and $\boldsymbol{n}$ : Using the above angle data and Eqs. (3), (9) and (17a), the three connection parameters are calculated and summarized in Table 3.

Table 3. Connection Parameters $(1 \mathrm{k}$-in. $=0.113 \mathrm{kN}-\mathrm{m})$

\begin{tabular}{|c|c|c|c|}
\hline Connection & $\begin{array}{c}\boldsymbol{R}_{\boldsymbol{k i}}\left(\times \mathbf{1 0}^{3}\right) \\
(\mathrm{k}-\mathrm{in} . / \mathrm{rad})\end{array}$ & $\begin{array}{c}\boldsymbol{M}_{\boldsymbol{u l t}} \\
(\mathrm{k}-\mathrm{in} .)\end{array}$ & $\boldsymbol{n}$ \\
\hline $\mathrm{C}(5 / 8)$ & 411 & 1907 & 1.37 \\
\hline $\mathrm{C}(3 / 4)$ & 690 & 2435 & 1.20 \\
\hline $\mathrm{C}(7 / 8)$ & 1112 & 2973 & 1.03 \\
\hline
\end{tabular}

Beam-Line Diagrams with $\boldsymbol{M}-\boldsymbol{\theta}$ Curves: The intersection of the $M-\theta$ curve and the beam line represents the expected connection moment and deformation under gravity loads. Using Eq. (1) for the $M$ - $\theta$ curves and Eq. (18) for the beam lines, one can generate Figure 9 for the three connections and the two load cases given in Table 1. The beam lines for the two load cases are labeled (BL-LC(I) and BL-LC(II), respectively, in the figure. From this figure, $R_{k b}$ for each connection can be determined as the slope of a line drawn from the origin to the intersection point of the connection's $M-\theta$ curve and the respective beam line. The calculated secant stiffness for each connection under Load Case $1 R_{k b l}$ is given in Table 4. 
Table 4. Connection Stiffness ( $1 \mathrm{k}-\mathrm{in} .=0.113 \mathrm{kN}-\mathrm{m})$

\begin{tabular}{|c|c|c|}
\hline Connection & $\begin{array}{c}\text { Connection Stiffness, } \boldsymbol{R}_{\boldsymbol{k b} \boldsymbol{1}}\left(\times \mathbf{1 0}^{\mathbf{3}}\right) \\
(\mathrm{k}-\mathrm{in} . / \mathrm{rad})\end{array}$ & $\overline{\boldsymbol{R}}_{k}=\boldsymbol{R}_{\boldsymbol{k} \boldsymbol{b} \boldsymbol{1}} \boldsymbol{L} / \boldsymbol{E I}$ \\
\hline $\mathrm{C}(5 / 8)$ & 435 & 8 \\
\hline $\mathrm{C}(3 / 4)$ & 314 & 5.8 \\
\hline $\mathrm{C}(7 / 8)$ & 202 & 3.7 \\
\hline
\end{tabular}

Connection C (3/4) is selected because its $\bar{R}_{k}$ value is closest to the initially assumed value of 6 . Once the connection has been selected, its $R_{k s}$ and $R_{k L}$ values can now be determined. By subjecting the frame to the service gravity load $(D+L), R_{k s} L / E I$ is computed to be 7.51, which falls in the PR connection range. From Figure 9 , the design strength $\left(\phi_{b} M_{n}(0.02 \mathrm{rad})\right)$ of the connection is determined to be $1987 \mathrm{k}$-in. $(225 \mathrm{kN}-\mathrm{m})$. Using the data presented in Figure 9 and the schematics shown in Figure 7, $R_{k b}$ and $R_{k L}$ for the two load cases are computed and given in Table 5.

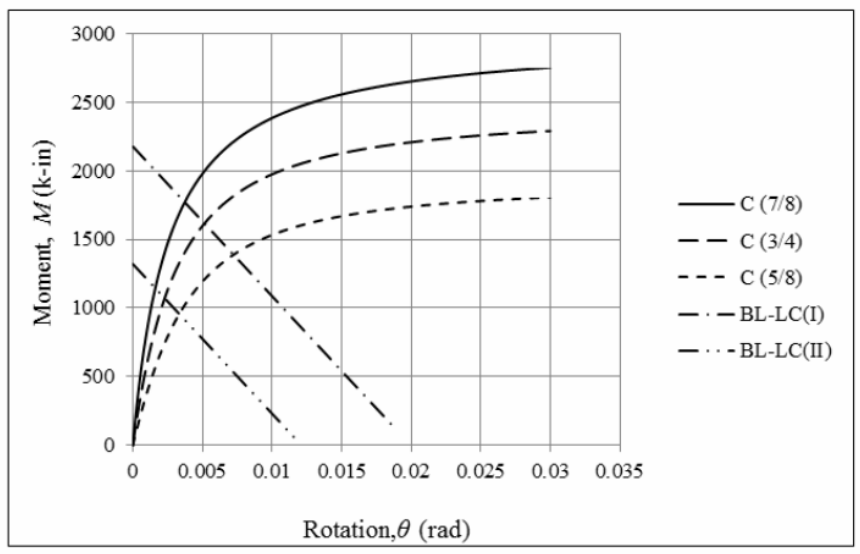

Figure 9. $M-\theta$ curves and beam lines $(1 \mathrm{k}-\mathrm{in} .=0.113 \mathrm{kN}-\mathrm{m})$

Table 5. Linearized Connection Stiffness (1 k-in./rad = $0.113 \mathrm{kN}-\mathrm{m} / \mathrm{rad})$

\begin{tabular}{|c|c|c|}
\hline \multirow{2}{*}{$\begin{array}{c}\text { Beam Line for Load Case } \\
\text { (BL-LC) }\end{array}$} & \multicolumn{2}{|c|}{ Linearized Connection Stiffness } \\
\cline { 2 - 3 } & $\begin{array}{c}\boldsymbol{R}_{\boldsymbol{k} \boldsymbol{b}}^{\left(\times \mathbf{1 0}^{\mathbf{3}}\right)} \\
(\mathrm{k}-\mathrm{in} . / \mathrm{rad})\end{array}$ & $\begin{array}{c}\boldsymbol{R}_{\boldsymbol{k} \boldsymbol{L}}\left(\times \mathbf{1 0}^{\mathbf{3}}\right) \\
(\mathrm{k}-\mathrm{in} . / \mathrm{rad})\end{array}$ \\
\hline 1 & 314 & - \\
\hline 2 & 467 & 64 \\
\hline
\end{tabular}

Column Section Selection: A W10 $\times 33$ section is selected based on the axial load $\left(P_{u}\right)$ and moment $\left(M_{n e g}\right)$ acting on the beam-column joint due to load case 1. A 12-ft long W10x33 section has an axial capacity $\left(\phi_{c} P_{n}\right)$ of 292 kips $(1300 \mathrm{kN})$ and bending moment capacity $\left(\phi_{b} M_{n}\right)$ of $1530 \mathrm{k}$-in. $(173 \mathrm{kN}-\mathrm{m})$.

Applying the Direct Analysis Approach: The analysis is carried out for the non-sway and sway frame conditions as outlined in Section 5.

Case 1 - the non-sway frame condition for gravity loads only

The parameters used for this analysis are summarized in Table 6 . 
Table 6. Case 1 Analysis Parameters $(1 \mathrm{k}=4.45 \mathrm{kN}, 1$ in. $=25.4 \mathrm{~mm})$

\begin{tabular}{|c|c|c|c|c|}
\hline \multicolumn{3}{|c|}{ Element Stiffness } & \multicolumn{2}{|c|}{ Applied Loads } \\
\hline $\begin{array}{c}\text { Columns } \\
E I_{e}=0.8 \tau E I \\
\left(\mathrm{k}-\text { in. }^{2}\right)\end{array}$ & $\begin{array}{c}\text { Beams } \\
E I_{e}=0.8 E I \\
\left(\mathrm{k} \text {-in. }{ }^{2}\right)\end{array}$ & $\begin{array}{c}\text { Connections } \\
0.9 R_{k b 1} \\
(\mathrm{k}-\mathrm{in} . / \mathrm{rad})\end{array}$ & $\begin{array}{c}\text { Load } \\
1.2 D+1.6 L \\
\text { (k/in.) }\end{array}$ & $\begin{array}{c}\text { Notional Load } \\
0.002 P_{i} \\
\text { (kips) }\end{array}$ \\
\hline $3.97 \times 10^{6}$ & $12.6 \times 10^{6}$ & $282 \times 10^{3}$ & 0.315 & 0.091 \\
\hline
\end{tabular}

( $\tau$ is taken as 1 since the axial load $P_{u}$ in each column for this load case is less than $0.5 P_{y}$.)

Using the above parameters, a second-order elastic analysis is performed to determine the internal forces in each member. The results are shown in Table 7. Also shown in the table are the results obtained from a $2^{\text {nd }}$-order inelastic analysis (i.e., instead of using the direct analysis approach outlined in Section 4, the frame is analyzed using $2^{\text {nd }}$-order inelastic analysis technique) as well as the results of the unity check obtained using the appropriate beam-column interaction (H1-1a or H1-1b) or beam equation given in AISC [22]. The unity check is satisfied if the value computed is $<1$. As can be seen, the results obtained using the direct analysis approach is slightly conservative when compared to those obtained from a $2^{\text {nd }}$-order inelastic analysis.

Table 7. Analysis Results for Case 1 with Unity Check $(1 \mathrm{kip}=4.45 \mathrm{kN}, 1 \mathrm{k}$-in. $=0.113 \mathrm{kN}-\mathrm{m})$

\begin{tabular}{|c|c|c|c|c|c|c|}
\hline \multicolumn{1}{|c|}{\begin{tabular}{c} 
Case 1 \\
Element \\
\cline { 2 - 7 }
\end{tabular}} & \multicolumn{2}{|c|}{$\begin{array}{c}\text { Moment } \\
(\mathrm{k} \text {-in.) }\end{array}$} & \multicolumn{2}{c|}{ Unity Check } \\
\cline { 2 - 7 } & $\begin{array}{c}\text { Proposed } \\
\text { Method }\end{array}$ & $\begin{array}{c}2^{\text {nd }} \text {-order } \\
\text { Inelastic } \\
\text { Analysis }\end{array}$ & $\begin{array}{c}\text { Proposed } \\
\text { Method }\end{array}$ & $\begin{array}{c}2^{\text {nd }} \text {-order } \\
\text { Inelastic } \\
\text { Analysis }\end{array}$ & $\begin{array}{c}\text { Proposed } \\
\text { Method }\end{array}$ & $\begin{array}{c}2^{\text {nd }} \text {-order } \\
\text { Inelastic } \\
\text { Analysis }\end{array}$ \\
\hline Left Column & 45.3 & 45.3 & 1029 & 992 & 0.75 & 0.73 \\
Right Column & 45.4 & 45.4 & 1040 & 1004 & 0.76 & 0.73 \\
Beam & - & - & 2246 & 2280 & 0.91 & 0.93 \\
\hline
\end{tabular}

$\underline{\text { Case } 2-\text { the sway frame condition for gravity }+ \text { wind loads }}$

The analysis parameters for this load case are given below.

(i) Gravity load step: $1.2 D+0.5 \mathrm{~L} \quad$ (see Table 8$)$

Table 8. Case 2 Gravity Load Analysis Parameters $(1 \mathrm{k}=4.45 \mathrm{kN}, 1$ in. $=25.4 \mathrm{~mm})$

\begin{tabular}{|c|c|c|c|c|}
\hline \multicolumn{3}{|c|}{ Element Stiffness } & \multicolumn{2}{c|}{ Applied Loads } \\
\hline $\begin{array}{c}\text { Columns } \\
E I_{e}=0.8 \tau E I \\
\left(\mathrm{k}-\mathrm{in} .{ }^{2}\right)\end{array}$ & $\begin{array}{c}\text { Beams } \\
I_{e}=0.8 E I \\
\left(\mathrm{k}-\mathrm{in} .{ }^{2}\right)\end{array}$ & $\begin{array}{c}\text { Connections } \\
0.9 R_{k b 2} \\
(\mathrm{k}-\mathrm{in} . / \mathrm{rad})\end{array}$ & $\begin{array}{c}\text { Loads } \\
1.2 D+0.5 L \\
(\mathrm{k} / \mathrm{in} .)\end{array}$ & $\begin{array}{c}\text { Notional Load } \\
0.002 P_{i} \\
(\mathrm{kips})\end{array}$ \\
\hline $3.97 \times 10^{6}$ & $12.6 \times 10^{6}$ & $420 \times 10^{3}$ & 0.191 & n.a \\
\hline
\end{tabular}


Table 9. Case 2 Lateral Load Analysis Parameters $(1 \mathrm{k}=4.45 \mathrm{kN}, 1 \mathrm{in}=25.4 \mathrm{~mm})$

\begin{tabular}{|c|c|c|c|c|c|c|}
\hline \multicolumn{4}{|c|}{ Element Stiffness } & \multicolumn{3}{|c|}{ Applied Loads } \\
\hline \multirow[b]{2}{*}{$\begin{array}{c}\text { Column } \\
E I_{e}=0.8 \tau E I \\
\left(\mathrm{k}-\mathrm{in} .{ }^{2}\right)\end{array}$} & \multirow[b]{2}{*}{$\begin{array}{c}\text { Beam } \\
E I_{e}=0.8 E I \\
\left(\mathrm{k}-\text { in. }^{2}\right)\end{array}$} & \multicolumn{2}{|c|}{ Connections } & \multicolumn{2}{|c|}{ Loads } & \multirow[b]{2}{*}{$\begin{array}{c}\text { Notional Load } \\
0.002 P_{i} \\
\text { (kips) }\end{array}$} \\
\hline & & $\begin{array}{c}0.9 R_{k i} \\
\text { (k-in./rad) }\end{array}$ & $\begin{array}{c}0.9 R_{k L} \\
\text { (k-in./rad) }\end{array}$ & $\begin{array}{c}\text { Column } \\
\text { Load } \\
\text { (kips) }\end{array}$ & $\begin{array}{l}\text { Wind } \\
1.0 \mathrm{~W} \\
\text { (kips) }\end{array}$ & \\
\hline $3.97 \times 10^{6}$ & $12.6 \times 10^{6}$ & $621 \times 10^{3}$ & $58 \times 10^{3}$ & 27.5 & 7.1 & 0.055 \\
\hline
\end{tabular}

Using the analysis parameters given in Tables 8 and 9, a second-order elastic analysis is performed individually for each load step to determine the internal forces in the structure. The results from these two analyses are then superimposed and presented in Table 10. Note that while the final moments are determined by superimposing the moment results from both the gravity and gravity+wind load steps, the final axial loads are determined only from the gravity+wind load step because the axial load effect from the gravity load step is already accounted for by subjecting the columns to the concentrated joint loads. Note also that the notional loads (representing non-verticality) are only applied in the gravity+wind load step to ensure that the second-order effects associated with the non-verticality are accounted for only once. Also shown in the table are results from a $2^{\text {nd }}$-order inelastic analysis and results of the unity check.

Table 10. Analysis Results for Case 2 with Unity Check $(1 \mathrm{kip}=4.45 \mathrm{kN}, 1 \mathrm{k}-\mathrm{in} .=0.113 \mathrm{kN}-\mathrm{m})$

\begin{tabular}{|c|c|c|c|c|c|c|}
\hline \multicolumn{7}{|c|}{ Case 2} \\
\hline \multirow[b]{2}{*}{ Element } & \multicolumn{2}{|c|}{$\begin{array}{c}\text { Axial Force } \\
\text { (kips) }\end{array}$} & \multicolumn{2}{|c|}{$\begin{array}{c}\text { Moment } \\
(\mathrm{k} \text {-in.) }\end{array}$} & \multicolumn{2}{|c|}{ Unity Check } \\
\hline & $\begin{array}{c}\text { Proposed } \\
\text { Method }\end{array}$ & $\begin{array}{l}2^{\text {nd }} \text {-order } \\
\text { Inelastic } \\
\text { Analysis }\end{array}$ & $\begin{array}{c}\text { Proposed } \\
\text { Method }\end{array}$ & $\begin{array}{l}2^{\text {nd }} \text {-order } \\
\text { Inelastic } \\
\text { Analysis }\end{array}$ & $\begin{array}{l}\text { Proposed } \\
\text { Method }\end{array}$ & $\begin{array}{l}2^{\text {nd }} \text {-order } \\
\text { Inelastic } \\
\text { Analysis }\end{array}$ \\
\hline Left Column & 26 & 26 & 404 & 392 & 0.33 & 0.3 \\
\hline Right Column & 29 & 29 & 809 & 778 & 0.57 & 0.56 \\
\hline Beam & - & - & 1382 & 1406 & 0.56 & 0.57 \\
\hline
\end{tabular}

Finally, the service live load deflection of the beam and the wind drift of the frame are calculated to be $0.41 \mathrm{in} .(10.4 \mathrm{~mm})$ and $0.32 \mathrm{in.}(8.1 \mathrm{~mm})$, respectively. Since they are less than the allowable values of $L / 360=0.8 \mathrm{in} .(20.3 \mathrm{~mm})$ and $H / 200=0.72 \mathrm{in} .(18.3 \mathrm{~mm})$, the design is considered satisfactory.

\section{Example 2 - Design of a Two-Story Unbraced PR Frame}

The PR frame subjected to the applied loads shown in Figure 10 is to be designed. The live load beam deflection and the wind induced interstory frame drift are to be limited to $L / 360$ and $H / 200$, respectively. To start the design, assume $\bar{R}_{k}=8$ and 10 for the $1^{\text {st }}$ and $2^{\text {nd }}$ story connections, respectively. 


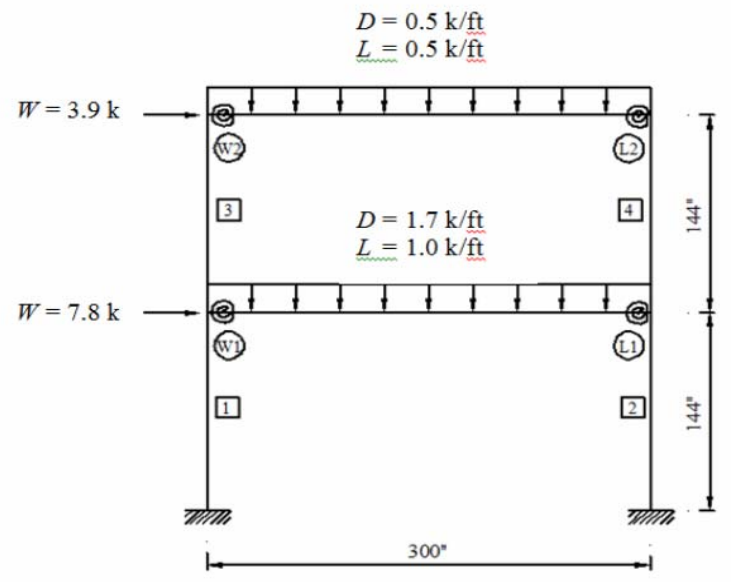

Figure 10. A Two-story Unbraced PR Frame $(1 \mathrm{k}=4.45 \mathrm{kN}, 1 \mathrm{ft}=12 "=0.305 \mathrm{~m})$

\section{Solution:}

The load combinations used for the design are given in Table 11. By using Load Case 1, Eqs. 19 and 20, and the assumed $\bar{R}_{k}$ values, $M_{n e g}$ and $M_{\text {pos }}$ are calculated and shown in Table 12. From these moment values, a W12×50 section $\left(\phi_{b} M_{n}=1903 \mathrm{k}\right.$-in. or $\left.215 \mathrm{kN}-\mathrm{m}\right)$ and a W10×33 section $\left(\phi_{b} M_{n}=912 \mathrm{k}\right.$-in. or $\left.103 \mathrm{kN}-\mathrm{m}\right)$ are selected for the beams of the first and second stories, respectively.

Table 11. Applied Loads $(1 \mathrm{k} / \mathrm{in} .=175 \mathrm{kN} / \mathrm{m}, 1 \mathrm{kip}=4.45 \mathrm{kN})$

\begin{tabular}{|c|c|c|c|c|c|}
\hline Load Case & Load Combinations & $\begin{array}{c}\boldsymbol{w}_{\boldsymbol{u} 1}(\mathrm{k} / \mathrm{in} .) \\
(\text { Gravity) }\end{array}$ & $\begin{array}{c}\boldsymbol{w}_{\boldsymbol{u} \mathbf{}}(\mathrm{k} / \mathrm{in} .) \\
(\text { Gravity) }\end{array}$ & $\begin{array}{c}\boldsymbol{p}_{\boldsymbol{u} \boldsymbol{1}}(\mathrm{kips}) \\
(\text { Lateral) }\end{array}$ & $\begin{array}{c}\boldsymbol{p}_{\boldsymbol{u} 2} \text { (kips) } \\
\text { (Lateral) }\end{array}$ \\
\hline 1 & $1.2 D+1.6 L$ & 0.303 & 0.117 & - & - \\
\hline 2 & $1.2 D+0.5 L+1.0 \mathrm{~W}$ & 0.212 & 0.071 & 7.8 & 3.9 \\
\hline
\end{tabular}

Table 12. Non-sway Beam Moments for Beam Section Selection $(1 \mathrm{k}-\mathrm{in} .=0.113 \mathrm{kN}-\mathrm{m})$

\begin{tabular}{|c|c|c|}
\hline Story & $\boldsymbol{M}_{\text {neg }}(\mathrm{k}$-in. $)$ & $\boldsymbol{M}_{\boldsymbol{p o s}}(\mathrm{k}-\mathrm{in})$. \\
\hline $1^{\text {st }}$ & 1818 & 1590 \\
\hline $2^{\text {nd }}$ & 731 & 585 \\
\hline
\end{tabular}

A set of possible top and seat angle with double web angle connections that can be used for the PR frame is given in Table 13. Using the values shown in this table, the connection parameters for the three-parameter model are calculated using Eqs. (3), (9), (17a) and are summarized in Table 14. The $M-\theta$ curves of these connections are plotted in Figures 11 and 12 together with the beam lines computed from Eq. (18) for the two load cases. From these figures, the secant stiffness for load case $1 R_{k b l}$ can be determined and are presented in Table 15. Connections $\mathrm{C}(3 / 4)$ and $\mathrm{C}(1 / 2)$ are selected because their $\bar{R}_{k}$ values are closest to their respective assumed values. Using the methodology depicted schematically in Figure 7, the linearized connection stiffness are determined for the two load cases and shown in Table 16. 


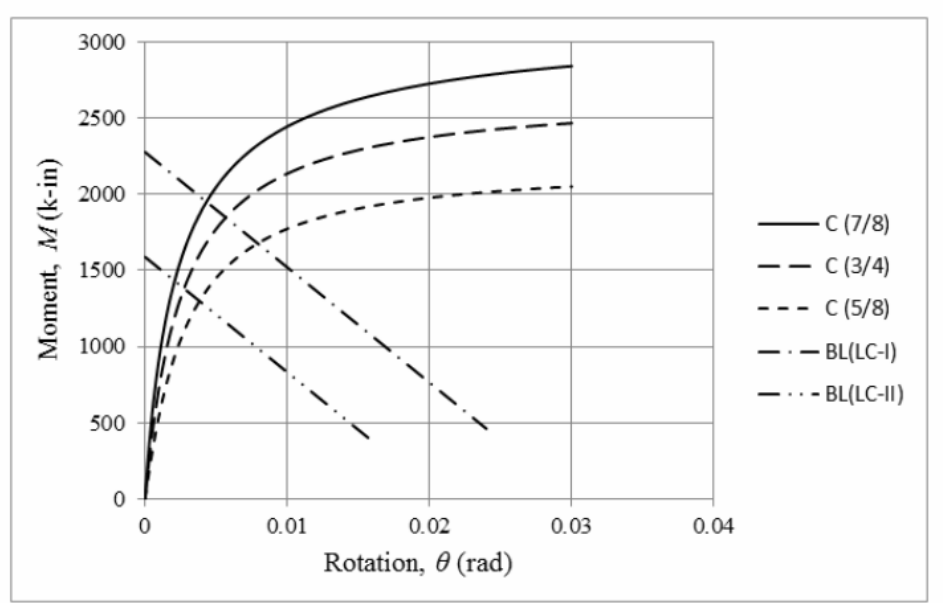

Figure 11. First Story $M-\theta$ Curves and Beam Lines $(1 \mathrm{k}-\mathrm{in} .=0.113 \mathrm{kN}-\mathrm{m})$

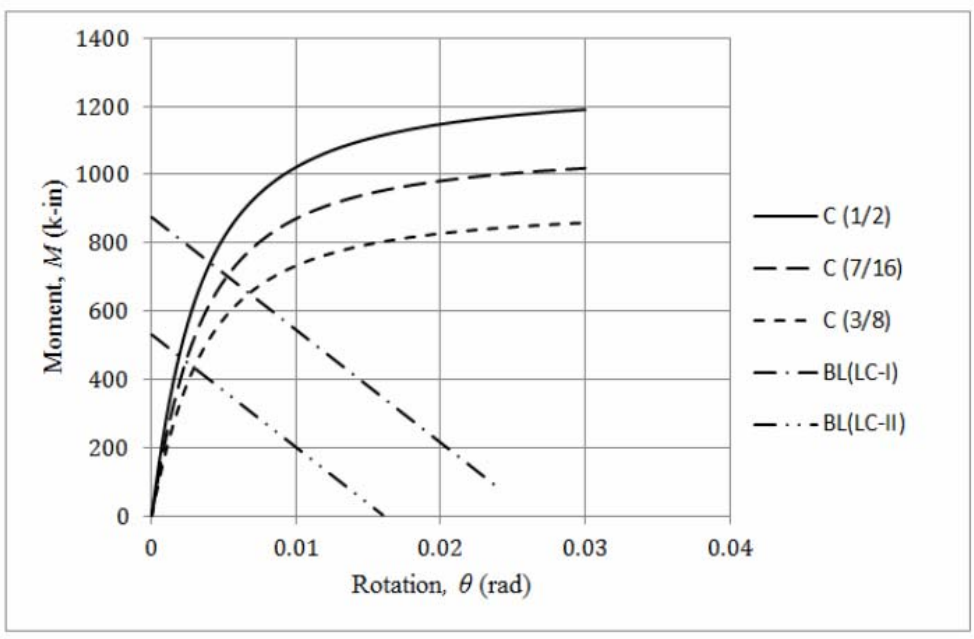

Figure 12. Second Story $M-\theta$ Curves and Beam Lines $(1 \mathrm{k}-\mathrm{in} .=0.113 \mathrm{kN}-\mathrm{m})$

Table 13. PR Connection Details $(1 \mathrm{in} .=25.4 \mathrm{~mm})$

\begin{tabular}{|c|c|c|c|c|c|c|c|c|c|}
\hline \multicolumn{10}{|c|}{$1^{\text {st }}$ Story } \\
\hline \multirow{2}{*}{ Connection } & \multirow{2}{*}{$\begin{array}{c}\text { Bolt } \\
\text { Diameter } \\
d \text { (in.) }\end{array}$} & \multirow{2}{*}{$\begin{array}{c}\text { Nut } \\
\text { Width } \\
W \text { (in.) }\end{array}$} & \multicolumn{4}{|c|}{$\begin{array}{c}\text { Top and Seat Angles } \\
2 \mathrm{~L} 6 \times 4 \times t_{t}\end{array}$} & \multicolumn{3}{|c|}{$\begin{array}{c}\text { Web Angles } \\
2 \mathrm{~L} 4 \times 4 \times 5 / 8\end{array}$} \\
\hline & & & $t_{t}$ (in.) & $l_{t}$ (in.) & $g_{c t}$ (in.) & $k_{t}$ (in.) & $l_{w}$ (in.) & $g_{c w}$ (in.) & $k_{w}$ (in.) \\
\hline $\mathrm{C}(5 / 8)$ & $7 / 8$ & $1-7 / 16$ & $5 / 8$ & 7 & 2.75 & $1-1 / 8$ & 8 & 2.5 & 1 \\
\hline $\mathrm{C}(3 / 4)$ & $7 / 8$ & $1-7 / 16$ & $3 / 4$ & 7 & 2.75 & $1-1 / 4$ & 8 & 2.5 & 1 \\
\hline $\mathrm{C}(7 / 8)$ & $7 / 8$ & $1-7 / 16$ & $7 / 8$ & 7 & 2.75 & $1-3 / 8$ & 8 & 2.5 & 1 \\
\hline \multicolumn{10}{|c|}{$2^{\text {nd }}$ Story } \\
\hline \multirow{2}{*}{ Connection } & \multirow{2}{*}{$\begin{array}{c}\text { Bolt } \\
\text { Diameter } \\
d \text { (in.) }\end{array}$} & \multirow{2}{*}{$\begin{array}{c}\text { Nut } \\
\text { Width } \\
W \text { (in.) }\end{array}$} & \multicolumn{4}{|c|}{$\begin{array}{cc}\text { Top } & \text { and Seat Angles } \\
2 \mathrm{~L} 6 \times 4 \times t_{t}\end{array}$} & \multicolumn{3}{|c|}{$\begin{array}{r}\text { Web Angles } \\
2 \mathrm{~L} 4 \times 3.5 \times 1 / 2 \\
\end{array}$} \\
\hline & & & $t_{t}$ (in.) & $l_{t}($ in. $)$ & $g_{c t}$ (in.) & $k_{t}$ (in.) & $l_{w}$ (in.) & $g_{c w}$ (in.) & $k_{w}$ (in.) \\
\hline $\mathrm{C}(3 / 8)$ & $7 / 8$ & $1-7 / 16$ & $3 / 8$ & 7 & 2.5 & $7 / 8$ & 8 & 2.25 & $7 / 8$ \\
\hline $\mathrm{C}(7 / 16)$ & $7 / 8$ & $1-7 / 16$ & $7 / 16$ & 7 & 2.5 & $15 / 16$ & 8 & 2.25 & $7 / 8$ \\
\hline $\mathrm{C}(1 / 2)$ & $7 / 8$ & $1-7 / 16$ & $1 / 2$ & 7 & 2.5 & 1 & 8 & 2.25 & $7 / 8$ \\
\hline
\end{tabular}


Table 14. Connection Parameters $(1 \mathrm{k}-\mathrm{in} .=0.113 \mathrm{kN}-\mathrm{m})$

\begin{tabular}{|c|c|c|c|}
\hline Connection & $\begin{array}{c}\boldsymbol{R}_{\boldsymbol{k i}}\left(\times \mathbf{1 0}^{\mathbf{3}}\right) \\
(\mathrm{kips}-\mathrm{in} . / \mathrm{rad})\end{array}$ & $\begin{array}{c}\boldsymbol{M}_{\text {ult }} \\
\text { (kips-in.) }\end{array}$ & $n$ \\
\hline \multicolumn{4}{|c|}{$1^{\text {st }}$ Story } \\
\hline $\mathrm{C}(5 / 8)$ & 686 & 2187 & 1.41 \\
\hline $\mathrm{C}(3 / 4)$ & 1010 & 2663 & 1.03 \\
\hline $\mathrm{C}(7 / 8)$ & 1497 & 3140 & 0.89 \\
\hline \multicolumn{4}{|c|}{$2^{\text {nd }}$ Story } \\
\hline $\mathrm{C}(3 / 8)$ & 212 & 908 & 1.32 \\
\hline$C(7 / 16)$ & 258 & 1077 & 1.31 \\
\hline $\mathrm{C}(1 / 2)$ & 322 & 1261 & 1.27 \\
\hline
\end{tabular}

Table 15. Connection Stiffness $(1 \mathrm{k}$-in. $=0.113 \mathrm{kN}-\mathrm{m})$

\begin{tabular}{|c|c|c|}
\hline Connection & $\begin{array}{c}\text { Connection Stiffness, } \boldsymbol{R}_{\boldsymbol{k b 1}}\left(\times \mathbf{1 0}^{\mathbf{3}}\right) \\
(\mathrm{k}-\mathrm{in} . / \mathrm{rad})\end{array}$ & $\overline{\boldsymbol{R}}_{k}=\boldsymbol{R}_{\boldsymbol{k b 1} 1} \boldsymbol{L} / \boldsymbol{E} \boldsymbol{I}$ \\
\hline \multicolumn{3}{|c|}{$1^{\text {st }}$ story } \\
\hline $\mathrm{C}(5 / 8)$ & 209 & 5.52 \\
\hline $\mathrm{C}(3 / 4)$ & 325 & 8.6 \\
\hline $\mathrm{C}(7 / 8)$ & 453 & 12 \\
\hline \multicolumn{3}{|c|}{$2^{\text {nd }}$ story } \\
\hline $\mathrm{C}(3 / 8)$ & 92 & 5.6 \\
\hline $\mathrm{C}(7 / 16)$ & 142 & 8.6 \\
\hline $\mathrm{C}(1 / 2)$ & 183 & 11 \\
\hline
\end{tabular}

Table 16. Linearized Connection Stiffness(1 k-in./rad =0.113 kN-m/rad)

\begin{tabular}{|c|c|c|c|c|}
\hline \multirow{2}{*}{$\begin{array}{c}\text { Beam Line for Load Case } \\
(\mathbf{B L - L C )}\end{array}$} & \multicolumn{4}{|c|}{ Linearized Connection Stiffness } \\
\cline { 2 - 5 } & \multicolumn{2}{|c|}{$\begin{array}{c}\boldsymbol{R}_{\boldsymbol{k} \boldsymbol{b}}\left(\times \mathbf{1 0}^{\mathbf{3}}\right) \\
(\mathrm{k}-\mathrm{in} . / \mathrm{rad})\end{array}$} & \multicolumn{2}{c|}{$\begin{array}{c}\boldsymbol{R}_{\boldsymbol{k} \boldsymbol{}}\left(\times \mathbf{1 0}^{\mathbf{3}}\right) \\
(\mathrm{k}-\mathrm{in} . / \mathrm{rad})\end{array}$} \\
\cline { 2 - 5 } & $1^{\text {st }}$ Story & $2^{\text {nd }}$ story & $1^{\text {st }}$ Story & $2^{\text {nd }}$ story \\
\hline 1 & 325 & 183 & - & - \\
\hline 2 & 572 & 246 & 66 & 38 \\
\hline
\end{tabular}

Based on $P_{u}$ and $M_{n e g}$ calculated for the gravity load case, a W10×33 $\left(\phi_{c} P_{n}=292 \mathrm{kips}\right.$ or $1300 \mathrm{kN}$, $\phi_{b} M_{n}=1530 \mathrm{k}$-in. or $173 \mathrm{kN}-\mathrm{m}$ ) is selected as a trial section for the columns. Because each end of the $1^{\text {st }}$ story beam is connected to two columns, a distribution factor based on the flexural stiffness of the columns above and below the beam as given by Eqs. (22a and 22b) can be used to apportion $M_{\text {neg }}$ to the columns.

$M_{\text {above }}=\frac{\left(\frac{I}{L}\right)_{\text {above }}}{\left(\frac{I}{L}\right)_{\text {above }}+\left(\frac{I}{L}\right)_{\text {below }}} M_{\text {neg }}$ 
$M_{\text {below }}=\frac{\left(\frac{I}{L}\right)_{\text {below }}}{\left(\frac{I}{L}\right)_{\text {above }}+\left(\frac{I}{L}\right)_{\text {below }}} M_{\text {neg }}$

Using the analysis parameters computed and given in Tables 17 and 18, a direct analysis as outlined in Section 4 is carried out for the two load cases. The results together with the $2^{\text {nd }}$-order inelastic analysis and unity check results are given in Table 19. As can be seen, good correlation is observed between the direct analysis results and those obtained using $2^{\text {nd }}$-order inelastic analysis. The unity check is also satisfied for all members.

Table 17. Case 1 Analysis Parameters $(1 \mathrm{k}=4.45 \mathrm{kN}, 1$ in. $=25.4 \mathrm{~mm})$

\begin{tabular}{|c|c|c|c|c|c|}
\hline \multirow{4}{*}{ Story } & \multicolumn{3}{|c|}{ Element Stiffness } & \multicolumn{2}{c|}{ Applied Loads } \\
\cline { 2 - 6 } & $\begin{array}{c}\text { Columns } \\
E I_{e}=0.8 \tau E I \\
\left(\mathrm{k}-\mathrm{in} .^{2}\right)\end{array}$ & $\begin{array}{c}\text { Beam } \\
E I_{e}=0.8 E I \\
\left(\mathrm{k}-\mathrm{in} .{ }^{2}\right)\end{array}$ & $\begin{array}{c}\text { Connections } \\
0.9 R_{k b 1} \\
(\mathrm{k}-\mathrm{in} . / \mathrm{rad})\end{array}$ & $\begin{array}{c}\text { Gravity Load } \\
1.2 D+1.6 L \\
(\mathrm{k} / \mathrm{in} .)\end{array}$ & $\begin{array}{c}\text { Notional Load } \\
0.002 P_{i} \\
(\mathrm{kips})\end{array}$ \\
\hline $1^{\text {st }}$ & $3.97 \times 10^{6}$ & $9.07 \times 10^{6}$ & $292 \times 10^{3}$ & 0.303 & 0.091 \\
\hline $2^{\text {nd }}$ & $3.97 \times 10^{6}$ & $3.97 \times 10^{6}$ & $165 \times 10^{3}$ & 0.117 & 0.035 \\
\hline
\end{tabular}

Table 18. Case 2 Analysis Parameters $(1 \mathrm{k}=4.45 \mathrm{kN}, 1$ in. $=25.4 \mathrm{~mm})$

\begin{tabular}{|c|c|c|c|c|c|c|c|c|}
\hline \multirow[b]{3}{*}{ Story } & \multicolumn{4}{|c|}{ Element Stiffness } & \multicolumn{4}{|c|}{ Applied Loads } \\
\hline & \multicolumn{8}{|c|}{ Gravity load step } \\
\hline & $\begin{array}{c}\text { Columns } \\
E I_{e}=0.8 \tau E I \\
\left(\mathrm{k}-\text { in. }^{2}\right)\end{array}$ & \multicolumn{2}{|c|}{$\begin{array}{c}\text { Beam } \\
E I_{e}=0.8 E I \\
\left(\mathrm{k}-\text { in. }{ }^{2}\right)\end{array}$} & \multicolumn{2}{|c|}{$\begin{array}{c}\text { Connections } \\
0.9 R_{k b 2} \\
(\mathrm{k}-\mathrm{in} . / \mathrm{rad}) \\
\end{array}$} & \multicolumn{2}{|c|}{$\begin{array}{c}\text { Load } \\
1.2 D+0.5 L \\
(\mathrm{k} / \mathrm{in} .) \\
\end{array}$} & $\begin{array}{c}\text { N.L } \\
0.002 P_{i} \\
\text { (kips) }\end{array}$ \\
\hline $1^{\text {st }}$ & $3.97 \times 10^{6}$ & \multicolumn{2}{|c|}{$9.07 \times 10^{6}$} & \multicolumn{2}{|c|}{$515 \times 10^{3}$} & \multicolumn{2}{|c|}{0.212} & - \\
\hline \multirow[t]{4}{*}{$2^{\text {nd }}$} & $3.97 \times 10^{6}$ & \multicolumn{2}{|c|}{$3.97 \times 10^{6}$} & \multicolumn{2}{|c|}{$222 \times 10^{3}$} & \multicolumn{2}{|c|}{0.071} & - \\
\hline & \multicolumn{8}{|c|}{ Lateral load step } \\
\hline & \multirow[b]{2}{*}{$\begin{array}{l}\text { Columns } \\
E I_{e}=0.8 \tau E I \\
\quad\left(\mathrm{k}-\mathrm{in}^{2}{ }^{2}\right)\end{array}$} & \multirow[b]{2}{*}{$\begin{array}{c}\text { Beam } \\
E I_{e}=0.8 E I \\
\left(\mathrm{k}-\mathrm{in}^{2}\right)\end{array}$} & \multicolumn{3}{|c|}{ Connections } & \multicolumn{2}{|c|}{ Load } & \multirow{2}{*}{$\begin{array}{c}\text { Notional } \\
\text { Load } \\
0.002 P_{i} \\
\text { (kips) }\end{array}$} \\
\hline & & & & $\begin{array}{l}.9 R_{k i} \\
\mathrm{n} . / \mathrm{rad})\end{array}$ & $\begin{array}{c}0.9 R_{k L} \\
\text { (k-in./rad) }\end{array}$ & $\begin{array}{l}\text { Column } \\
\text { Load } \\
\text { (kips) }\end{array}$ & $\begin{array}{l}\text { Wind } \\
1.0 W \\
\text { (kips) }\end{array}$ & \\
\hline $1^{\text {st }}$ & $3.97 \times 10^{6}$ & $9.07 \times 10^{6}$ & & $9 \times 10^{3}$ & $59 \times 10^{3}$ & 31.8 & 7.8 & 0.064 \\
\hline $2^{\text {nd }}$ & $3.97 \times 10^{6}$ & $3.97 \times 10^{6}$ & & $0 \times 10^{3}$ & $34 \times 10^{3}$ & 10.6 & 3.9 & 0.021 \\
\hline
\end{tabular}

The service live load deflections of the $1^{\text {st }}$ and $2^{\text {nd }}$ story beams are computed to be $0.37 \mathrm{in}$. (9.4 mm) and 0.44 in. $(11.1 \mathrm{~mm})$, respectively, and the wind induced interstory drifts of the frame are calculated to be 0.62 in $(15.7 \mathrm{~mm})$ for the $1^{\text {st }}$ story and $0.68 \mathrm{in} .(17.2 \mathrm{~mm})$ for the $2^{\text {nd }}$ story. They are within the allowable values of $L / 360=0.833 \mathrm{in}$. $(21.2 \mathrm{~mm})$ for beam deflection and $H / 200=0.72$ in. $(18.2 \mathrm{~mm})$ for interstory drift, and so the design is considered satisfactory. 
Table 19. Analysis results for Cases 1 and 2 with Unity Check

$(1 \mathrm{kip}=4.45 \mathrm{kN}, 1 \mathrm{k}$-in. $=0.113 \mathrm{kN} / \mathrm{m})$

\begin{tabular}{|c|c|c|c|c|c|c|c|}
\hline \multirow[b]{2}{*}{$\begin{array}{l}\text { Load } \\
\text { Case }\end{array}$} & \multirow[b]{2}{*}{ Element } & \multicolumn{2}{|c|}{$\begin{array}{l}\text { Axial Force } \\
\text { (kips) }\end{array}$} & \multicolumn{2}{|c|}{$\begin{array}{c}\text { Moment } \\
\text { (k-in.) }\end{array}$} & \multicolumn{2}{|c|}{ Unity Check } \\
\hline & & $\begin{array}{c}\text { Proposed } \\
\text { method }\end{array}$ & $\begin{array}{l}2^{\text {nd }} \text {-order } \\
\text { Inelastic } \\
\text { Analysis }\end{array}$ & $\begin{array}{c}\text { Proposed } \\
\text { method }\end{array}$ & $\begin{array}{l}2^{\text {nd }} \text {-order } \\
\text { Inelastic } \\
\text { Analysis }\end{array}$ & $\begin{array}{c}\text { Proposed } \\
\text { method }\end{array}$ & $\begin{array}{l}2^{\text {nd }} \text {-order } \\
\text { Inelastic } \\
\text { Analysis }\end{array}$ \\
\hline \multirow{6}{*}{1} & Col 1 & 63 & 63 & 685 & 662 & 0.61 & 0.60 \\
\hline & Col 2 & 63 & 63 & 699 & 676 & 0.62 & 0.61 \\
\hline & Col 3 & 17.5 & 17.5 & 866 & 836 & 0.60 & 0.58 \\
\hline & Col 4 & 17.6 & 17.6 & 870 & 840 & 0.60 & 0.58 \\
\hline & $1^{\text {st }}$ story Beam & - & - & 1843 & 1897 & 0.97 & 0.99 \\
\hline & $2^{\text {nd }}$ story Beam & - & - & 637 & 656 & 0.69 & 0.72 \\
\hline \multirow{6}{*}{2} & Col 1 & 38 & 39 & 349 & 347 & 0.33 & 0.3 \\
\hline & Col 2 & 46 & 46 & 826 & 809 & 0.64 & 0.61 \\
\hline & Col 3 & 9.5 & 9.5 & 440 & 423 & 0.30 & 0.3 \\
\hline & Col 4 & 12 & 12 & 687 & 665 & 0.47 & 0.45 \\
\hline & $1^{\text {st }}$ story Beam & - & - & 1350 & 1388 & 0.71 & 0.73 \\
\hline & $2^{\text {nd }}$ story Beam & - & - & 412 & 423 & 0.45 & 0.46 \\
\hline
\end{tabular}

\section{SUMMARY AND CONCLUSIONS}

A procedure for the design of partially-restrained (PR) frames is proposed. In a PR frame, the connections used to connect the beams and columns are semi-rigid in nature. According to AISC [22], a connection is considered semi-rigid if the ratio of its secant stiffness under service load $R_{k s}$ to the beam stiffness $E I / L$ falls in the range $2<R_{k s} L / E I<20$. The proposed procedure makes use of the three-parameter connection model to describe the nonlinear connection moment-rotation $(M-\theta)$ behavior and the direct analysis approach to perform the frame analysis. To proceed with the design, a connection stiffness $R_{k b}$ defined as the slope of a line drawn from the origin to the intersection point of the nonlinear $M-\theta$ curve and the beam line constructed for the factored gravity load case under consideration is used. Loading and unloading behavior of the PR connections are accounted for by the use of two different stiffness $R_{k L}$ and $R_{k i}$; the former is obtained from linearization of the $M-\theta$ curve and the latter is obtained from the three-parameter connection model.

Trial beam sections are selected based on the beam moments $M_{\text {pos }}$ and $M_{\text {neg }}$ calculated using a target value of $\bar{R}_{k}=R_{k b} L / E I$ for the connections under factored gravity loads. The connections are then selected based on the proximity of their $\bar{R}_{k}$ values to those of the target values. Once the connections are selected, trial column (beam-column to be exact) sections can be selected based on the approximate $P_{u}$ and $M_{u}$ values computed from the applied gravity loads and $M_{n e g}$ of the adjoining connections, respectively.

Examples of PR frames designed using top and seat with web angle connections were given to demonstrate the steps involved in applying the proposed method in PR frame design. It was shown that despite its simplicity, the proposed approach yields good results when compared to a $2^{\text {nd }}$-order inelastic analysis. 


\section{REFERENCES}

[1] Ang, K.M. and Morris, G.A., "Analysis of Three-Dimensional Frames with Flexible Beam-Column Connections", Canadian Journal of Civil Engineers, 1984, Vol. 11, pp. 245-254.

[2] Lui, E.M. and Chen, W.F., "Analysis and Behavior of Flexibly Jointed Frames," Engineering Structures, 1986, Vol. 8, No. 2, pp. 107-118.

[3] Lui, E.M. and Chen, W.F., "Steel Frame Analysis with Flexible Joints", Journal of Construction Steel Research, 1987, Vol. 8, pp. 161-202.

[4] Lui, E.M. and Chen, W.F., "Behavior of Braced and Unbraced Semi-Rigid Frames", International Journal of Solids and Structures, 1988, Vol. 24, No. 9, pp. 893-913.

[5] Chen, W.F., "Joint Flexibility in Steel Frames," Journal of Constructional Steel Research, 8, Special Issue, 1987.

[6] Cunningham, R., "Some Aspects of Semi-Rigid Connections in Structural Steelwork", the Structural Engineer, 1990, Vol. 68, No. 5, pp. 85-92.

[7] Wu, F. S., and W. F. Chen (1990), "A Design Model for Semi-Rigid Connections," Engineering Structures, 1990, Vol. 12, No. 2, pp. 88-97.

[8] Barakat, M., and Chen W. F., "Practical Analysis of Semi-Rigid Frames," Engineering Journal, AISC, 1990, Vol. 27, No. 2, pp. 54-68.

[9] Barakat, M., and Chen W. F., "Design Analysis of Semi Rigid Frames: Evaluation and Implementation," Engineering Journal, AISC, 1991, Vol. 28, No. 2, pp. 55-64.

[10] Hsieh, S. H., and Deierlein, G. C., "Nonlinear Analysis of Three-Dimensional Steel Frames with Semi-Rigid Connections," Computer and Structures, 1991, Vol. 41, No. 5, pp. 995-1009.

[11] Lui, E.M., "Stability Design of Partially Restrained Frames", Fifth International Colloquium on Stability of Metal Structures, Chicago, IL, 1996, pp. 259-268.

[12] Xu, L., "Semirigid Frame Structures", Chapter 23, in Handbook of Structural Engineering, $2^{\text {nd }}$ edition, W.F. Chen and E.M. Lui (editors), CRC Press, Boca Raton, FL., 2005.

[13] Surovek, A.E., White D.W., and Leon, R.T., "Direct Analysis for Design Evaluation of Partially-Restrained Steel Framing Systems," Journal of Structural Engineering, ASCE, 2005, Vol. 131, No. 9, pp. 1376-1389.

[14] Narayanan, R., Structural Connections: Stability and Strength, EF Spon/Routledge, New York, N.Y., 1990.

[15] Lorenz, R.F., Kato, B., and Chen W.F., "Semi-rigid Connections in Steel Frames", Council on Tall Buildings and Urban Habitat, Committee 43, McGraw-Hill, New York, NY., 1993.

[16] Chen, W.F., Goto, Y., and Liew, J.Y.R., Stability Design of Semi-Rigid Frames, John Wiley and Sons, New York, N.Y., 1996.

[17] Bjorhovde, R., Colson, A., and Zandonini, R., Connections in Steel Structures III, Pergamon Press, Oxford, U.K., 1996.

[18] Chan, S.L. and Chui, P.P.T., Non-linear Static and Cyclic Analysis of Steel Frames with Semi-Rigid Connections, Elsevier Science, Oxford, UK., 2000.

[19] Chen, W.F., Practical Analysis for Semi-Rigid Frame Design, World Scientific, Singapore, 2000.

[20] Faella, C., Piluso, V., and Rizzano, G., Structural Steel Semirigid Connections, CRC Press, Boca Raton, FL., 2000.

[21] Chen, W.F., Kishi, N., Komuro, M., Semi-rigid Connections Handbook, J. Ross Publishing, Fort Lauderdale, FL., 2011.

[22] AISC Specification for Structural Steel Buildings, American Institute of Steel Construction, Inc., Chicago, IL., 2010.

[23] Cerfontaine, F. and Jaspart, J.P., "Analytical Study of the Interaction between Bending and Axial Force in Bolted Jointed”, In: Eurosteel, Coimbra, 2002, pp. 997-1006. 
[24] Urbonas, K. and Daniunas, A., "Component Method Extension to Steel Beam-to-Beam and Beam-to-Column Knee Joints Under Bending and Axial Forces", Journal of Civil Engineering and Management, XI (3), 2005, pp. 217-224.

[25] Urbonas, K. and Daniunas, A., "Behaviour of Semi-Rigid Steel Beam-to-Beam Joints Under Bending and Axial Forces", Journal of Constructional Steel Research, 2006, Vol. 62, pp. 1244-1249,

[26] Frye, M.J. and Morris, G.A., "Analysis of Flexibly Connected Steel Frames", Canadian Journal of Civil Engineers, 1975, Vol. 2, No. 3, pp. 280-291.

[27] Goverdhan, A.V., A Collection of Experimental Moment-Rotation Curves and the Evaluation of Predicting Equations for Semi-Rigid Connections, M.S. Thesis, Vanderbilt University, Nashville, TN., 1983.

[28] Nethercot, D.A., "Steel Beam-to-Column Connections - A Review of Test Data and its Applicability to the Evaluation of Joint Behavior in the Performance of steel Frames", CIRIA Project Study, 1985.

[29] Kishi, N. and Chen, W.F., "Data Base of Steel Beam-to-Column Connections", Structural Engineering Report, CE-STR-86-26, School of Civil Engineering, Purdue University, West Lafayette, IN., 1986.

[30] Chen, W.F. and Kishi, N., "Semi-Rigid Steel Beam-to-Column Connections: Data Base and Modeling," Journal of Structural Engineering, ASCE, 1989, Vol. 115, No. 1, pp. 105-119.

[31] Bjorhovde, R., Colson, A., and Brozzetti, J., "Classification System for Beam-to-Column." Journal of Structural Engineering, ASCE, 1990, Vol. 116, No. 11, pp. 3059-3076.

[32] Eurocode 3, "Design of Steel Structures - Part 1-1: General Rules and Rules for Buildings", EN 1993, European Committee for Standardisation (CEN), 1993.

[33] Nethercot, D.A., Ahmed, T.Q., and Li, B., "Unified Classification System for Beam-to-column Connections", J. of Constructional Steel Research, 1998, Vol. 45, No. 1, pp. 39-65.

[34] Chen, W.F. and Lui, E.M., Stability Design of Steel Frames, CRC Press, Boca Raton, FL., 1991.

[35] PRCONN, Moment-Rotation Curves for Partially Restrained Connections, RMR Design Group, Inc., Tucson, AZ., 1993.

[36] Chen, W.F. and Toma, S., Advanced Analysis of Steel Frames - Theory, Software and Applications, CRC Press, Boca Raton, FL., 1994.

[37] Kishi, N., Chen, W.F., Matsuoka, K.G., and Nomachi, S.G., "Moment-Rotation Relation of Top-and Seat-Angle with Double Web-Angle Connections," Proceedings of the State-of-the-Art Workshop on Connections and the Behavior, Strength and Design of Steel Structures, R. Bjorhovde, J. Brozzetti, and A. Colson, eds., Ecole Normale Superieure de Cachan, France, May 25-27, 1987, London: Elsevier, pp. 121-134.

[38] Kishi, N., Chen, W.F., Matsuoka, K.G., and Nomachi, S.G., "Moment-Rotation Relation of Single/ Double Web-Angle Connections," Proceedings of the State-of-the-Art Workshop on Connections and the Behavior, Strength and Design of Steel Structures, R. Bjorhovde, J. Brozzetti, and A. Colson, eds., Ecole Normale Superieure de Cachan, France, May 25-27, 1987, London: Elsevier, pp. 135-149.

[39] Kishi, N. and Chen, W.F., "Moment-Rotation Relations of Semi-Rigid Connections with Angles, Journal of Structural Engineering", ASCE, 1990, Vol. 116, No. 7, pp. 1813-1834.

[40] Richard, R. M., and B. J. Abbott (1975), "Versatile Elastic-Plastic Stress-Strain Formula," Journal of Engineering Mechanics Division, ASCE,1975, Vol. 101, No. 4, pp. 511-515.

[41] Kishi, N., Chen, W.F., Goto, Y., and Matsuoka, K.G., "Design Aid of Semi-Rigid Connections for Frame Analysis", Engineering Journal, AISC, 1993, Vol. 30, No. 3, pp. 90-107.

[42] Christopher, J. E., and Bjorhovde, R., "Semi-Rigid Frame design for Practicing Engineers" Engineering Journal, AISC, 1999, Vol. 36, No. 1, pp. 12-28. 
[43] McGuire, W., Gallagher, R. H., and Ziemian, R. D., Matrix Structural Analysis, $2{ }^{\text {nd }}$ Edition, Wiley, New York, 2000.

[44] ASCE Minimum Design Loads for Buildings and Other Structures, ASCE/SEI 7-10, American Society of Civil Engineers, Reston, VA., 2010. 